\title{
THE BUSINESS MODEL OF JOURNALISM START-UPS IN CHINA
}

\author{
Dr. Shixin Ivy Zhang \\ University of Nottingham Ningbo China
}

This study has addressed the emerging business models for journalism start-ups in China. The author proposed a new analytical model to study six components of a business model namely the consumer, the niche, the delivery, the revenue, the funding model, and the profit sharing mode. Applying this model in eight selected cases in China, this article typologies five business models: 1) Platform-oriented News Aggregator; 2) Platform-oriented Service Provider; 3) Contentoriented News Site; 4) Content-oriented Trade Journal; and 5) Content-oriented We-media. The author argues that Chinese journalism start-ups have explored innovative business models in China's particular political and social context. The state media policy, market and technology are three main driving forces for the business model.

KEYWORDS business model; China; innovation; journalism start-up; media business; niche

\section{Introduction}

On October 16, 2017, Caixin Media, China's leading financial and investigative news provider based in Beijing, announced that it would charge readers to use its online platform. As Chinese internet users have long been accustomed to consuming free news, such a move made Caixin, in the words of the Chinese proverb, "the first one to eat crabs" in China's media market. This user-end income now accounts for less than 10 per cent of Caixin's income, while ads remain a major source of its income (tmtpost 2017).

However, while Caixin may be the first media outlet to implement a paywall for its news coverage in China, it is not the first to explore new business models. In late 2013, Zhongchou.com, one of the leading crowd-funding platforms in China, launched a crowd-funded news channel to provide a platform for news content that is problematic in the traditional Chinese media, though this soon dissolved due to the associated political risks (Liu 2016).

Such examples illustrate how Chinese journalism is currently undergoing significant changes driven by both the advent of digital technology and audiences' changing news consumption patterns. In face of the wider journalism crisis of declining circulation and advertising revenue, both old and new media outlets are exploring alternative and feasible business models to monetize news content and generate revenue, including the renewed introduction of pay walls and targeted advertising based on data mining and user profiles. As scholars have pointed out, such experimentation with existing business models is a crucial part of moving forward and adapting this industry in the contemporary age (Leurdijk, 2014:156).

Existing English-language scholarships focused upon business models in digital journalism mainly focus upon digital paywalls (digital subscription model), paying intent (willingness to pay) (e.g. Chyi, 2012; Pickard and Williams, 2014) and news micropayment (e.g. Graybeal and Hayes, 2011). Financial sources that scholars have identified include the use of news aggregators, news syndicators, tip jars, non-profit models, hyper-local sites, registration, partnering, portal approaches, branded content and advertising. Such sources enjoy different 
levels of popularity: paywalls, subscriptions and freemium models are the most popular methods to charge for content, while affiliate marketing, donations, selling data or services, organizing events, freelancing and training or selling merchandise are less popular (Sirkkunen and Cook 2012).

Existing research addressing business models of media and journalistic start-ups mainly focuses upon case studies and situations in America and Europe, these generally take a broad brush approach and paint a gloomy picture of the fate of legacy media in Western countries (Sirkkunen and Cook 2012). Yet studies addressing business models of journalistic start-ups in non-Western countries such as China are limited and there is no integrated analytical model addressing the business side of digital journalism in this context.

Responding to this research gap, this study will propose a new business model for digital journalism with an academic focus upon China. The article will propose and theorize a new integrated business model for digital journalism that has been applied and tested in case studies of Chinese journalism start-ups. Using the model as theoretical framework and drawing on a review of secondary literatures, this study generalizes five types of business models for digital journalism in China: 1) Platform-oriented News Aggregator; 2) Platform-oriented Service Provider; 3) Content-oriented News Site Only; 4) Content-oriented Trade Journal; and 5) Content-oriented We-media. It argues that Chinese journalism start-ups explore innovative business models that are appropriate to China's particular political and social context, in which the state media policy, market and technology are the three main driving forces.

\section{Proposing a New Model for Digital Journalism}

Over the last few years, the concept of a 'business model' has become a globally significant phenomenon since this became associated with securing a competitive advantage in the wider economic market (Wirtz et. al 2016). However, the application of this phenomenon across some very different economic areas has led to a rather vague and heterogeneous understanding of this concept (ibid). Definitions differ across studies, with Teece's $(2010,172)$ definition of a business model as the 'design or architecture of the value creation, delivery, and capture mechanisms' of a firm currently the most consistent (Foss \& Saebi 2017).

Teece (2010) further claims that a business model is a conceptual, rather than financial, model of a business, while Pickard (2011) points out that business models 'conceptualize the underlying business logic of an enterprise' (ibid). As a theoretical concept, the notion of a business model has been broken down into different components (Wirtz et. al 2016), with Wirtz's $(2011,70)$ 's integrated business model combining six components including market model, capital model, distribution model, service model, production model and procurement model. As a generic model, this can be applied to any industry or sector but is generally problematic when applied to journalism. News and information providers have their own particular production and distribution process, and the procurement model in particular does not seem appropriate as a tool of analysis for the journalism industry. In comparison, Fetscherin and Knolmayer (2011)'s content delivery model is much more targeted and subject-specific. This model consists of five components: the product, the consumer, the revenue, the price, and the delivery, yet this model still has limitations when confronted with digital journalism. For instance, the price is less important for digital journalism and method by which users are charged does not generally affect paying intent (instead, this is affected by whether they are charged in the first place, a phenomenon often labelled as the "penny gap" or "price of zero") (Chyi 2012). 
Instead a profit-sharing model enables theorists to address wider questions around the future of news-related business, including how advertising and other similar sources of revenue can be distributed between providers and contributors (Leurdijk 2014, 156).

On the basis of the two above-mentioned established frameworks and considering the distinctive features, changes and practices in digital journalism, this paper proposes the following model (Figure 1) as a means through which to study and examine the business side of digital journalism. It integrates six components including the consumer, the niche, the delivery, the revenue, the funding model and the profit sharing mode, each of which I will explore in depth.

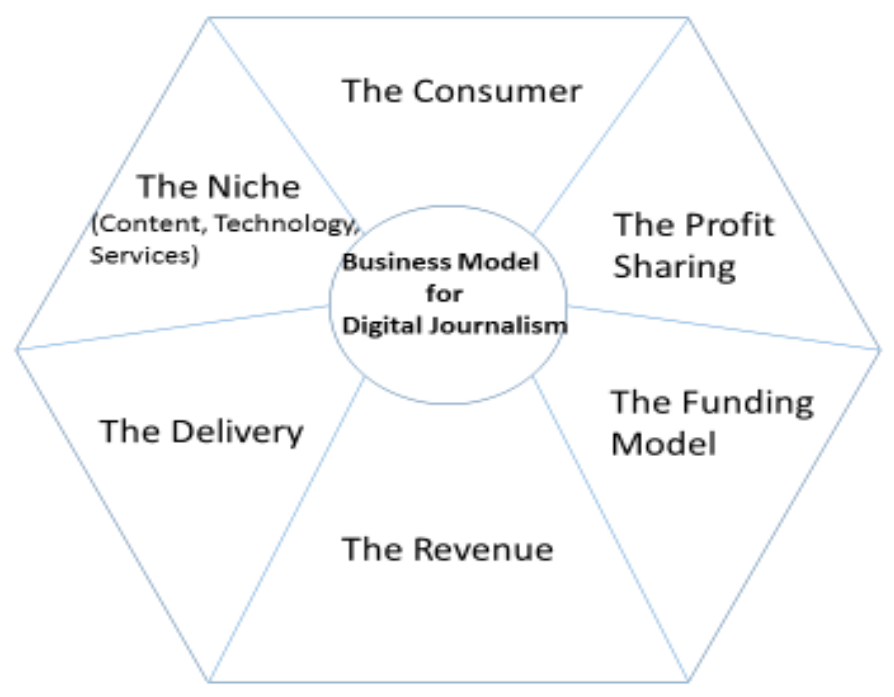

Figure 1: An integrated business model for digital journalism

The consumer is an essential component of the business model, constituting 'the foundation for subscription and advertising revenue' (Chyi and Tenenboim 2017). The position and construction of this notion is generally similar to that in the conventional market or target market model, which focuses upon the profiling of current and target news users, readers or consumers. In the case of online news economics, Chyi and Lee (2013)'s study identifies five factors - preference, use, paying intent, age and gender- in users' news consumption, of which format preference and news interest are the most critical in the print business model. In their analysis, Chyi and Tenenboim (2017) challenge the US newspapers' 'digital first' strategy and claim that part of the difficulty in monetizing digital content lies in readership.

However, in China, as of June 2017, the number of Internet users has reached 751 million with a penetration rate of 54.3\%. Mobile-based web users has reached 724 million accounting for $96.3 \%$ of the total web users (CNNIC 2017). Mobile access is therefore a central part of this contemporary new consumption experience in China, and out of 625 million online news users, 596 million use their mobile to access news (ibid). Identifying the current and target news users in a particular market is therefore an essential part of a business model.

The second component of this model is 'the niche'. Rather than a broad term of product, value creation or core competencies, the niche here refers to the media outlet's specialized 
content, technology or services. The niche highlights specialization and differentiation, and so offers an approach to digital news that may be the greatest hope for sustainability (Gahran 2013). Chris Anderson $(2007,52)$ outlines this importance, claiming that "our culture and economy are shifting away from a focus on mainstream products and markets at the head of demand curve, and moving towards a huge number of niches in the tail'". In journalism studies, niche relates to "narrow-interest content serving specific-interest audiences" (Cook and Sirkkunen 2013), illustrated through the shift in content from news for citizens (generally news) to news for consumers (niche news) (Machin and Niblock 2007; Cook and Sirkkunen 2013). New media first sought an area of specialization (a niche) and then searched for financial stability in the form of technology, products and/or services for news sites (Cook and Sirkkunen 2013).

Thirdly, 'delivery' refers to the ways in which news organisations distribute and disseminate news and information through multiple media platforms, the so called multiplatform or cross-platform delivery, in order to sustain and reach the widest audiences. This multi-platform distribution is not new to Chinese news organisations, which have long since incorporated the widespread availability of mobile phones and the rapid growth of social media such as Weibo and WeChat. In 2017, Tencent's WeChat, an instant messaging application, had "963 million monthly active users, closing in on 1 billion users" (statista.com) while in the same year, Sina Weibo's (microblogging) monthly active users reached 340 million. WeChat and Weibo now form a "central part of social activity in China, certainly for younger people" (Sparks et al 2016) and this study likewise explores case studies of the use of delivery platforms by Chinese journalism star-ups.

Revenue streams are the fourth component of the model. A viable economic model for media must rely upon a corresponding multi-dimensional revenue model that includes both paid content and online and mobile advertising (Pavlik 2013). Paywall, a digital subscription scheme for paid content, has become an industry standard here, though researchers find that paywalls are not a reasonable revenue model as they cannot offset the corresponding decline in traffic that then creates a significant loss in advertising revenue (Pickard and Williams 2014; Brandstetter and Schmalhofer 2014).

Indeed, advertising is still the primary source for many news outlets, and the increasing convergence between mobile device use and social media engagement certainly presents a growing revenue opportunity in this area (Pavlik 2013). However, social media's contribution to the relationship between increased web traffic and increased advertising revenue is underwhelming (Ju, Jeong and Chyi, 2014), with studies arguing that social media is not actually saving the newspaper industry financially (Lee, 2015).

Given the importance of innovation in the digital age (Pavlik 2013), journalism start-ups become significant due to their small size and corresponding flexibility. Such start-ups are significantly innovative in business models due to their identification of both new revenue streams and the diverse nature of their revenue sources (Sirkkunen and Cook 2012). In this research, Chinese journalism start-ups' revenue streams will be explored.

As the fifth component of this framework, the funding model outlines the new and different revenue streams that are now part of media outlets and their funding sources. Stetka1 and Örnebring (2013) identify two main funding models, for-profit and non-profit. While the profit oriented model consists of traditional/legacy media and online only media, the non-profit oriented model includes state funding (public service broadcasting), foundation/charitable funding and membership funding. 
In China, there are two general categories of news media - state-owned media and their digital units as well as commercial digital media (platforms, news apps, portals, social media, websites, etc.). While Chinese newspapers are beginning to feel the effects of digital media both on their circulations and advertising revenues, the Chinese government has "urged media to adapt more rapidly and fully to the new technologies, providing state funds to accelerate the transition" (Sparks et al, 2016).

The profit sharing model is the sixth component of this framework, and refers to 'big media platforms providing copyright fees and subsidy' to media companies and individuals (Xia 2017). This component serves to encourage news outlets and individuals to produce and supply good text and video content to the online platforms, thus attracting audience attention and so bringing increased advertising and profit (ibid). This model mainly applies to news aggregators, and offers a potential solution to legality issues around the monetizing of third-party content. In China, media platforms such as Toutiao, Tencent and Baidu have adopted this model. This study in particular examines the implementation, practices and issues of Toutiao's profit-sharing model.

Through deploying the various levels of this business model for digital journalism, this study addresses journalism start-ups in China. I seek to outline both the existing business models for Chinese journalism start-ups as well as identify the driving forces that influence and shape these various models.

\section{Research Methods}

This study uses a qualitative approach to analysis, including case studies, semi-structured interviews, and secondary literatures. Eight Chinese journalistic start-ups were selected including Toutiao, The Paper, Airtime Weekly (Airtime), SciTech Life Weekly (SciTech), donews.com, as well as three WeChat public accounts. Table 1 gives basic information about these eight start-ups.

\begin{tabular}{|l|l|l|l|l|}
\hline Name & Web link & $\begin{array}{l}\text { Year of } \\
\text { Establishme } \\
\text { nt }\end{array}$ & Location & Ownership \\
\hline Toutiao & www.toutiao.c & 2012 & Beijing & $\begin{array}{l}\text { Beijing Byte } \\
\text { Science \& } \\
\text { Technology } \\
\text { Co., Ltd. }\end{array}$ \\
\hline
\end{tabular}




\begin{tabular}{|c|c|c|c|c|}
\hline The Paper & $\begin{array}{l}\text { www.thepaper. } \\
\text { cn }\end{array}$ & 2014 & Shanghai & $\begin{array}{l}\text { Shanghai } \\
\text { Media } \\
\text { Group }\end{array}$ \\
\hline Airtime Weekly & n./a. & 2011 & Beijing & $\begin{array}{l}\text { Beijing } \\
\text { Youth Daily }\end{array}$ \\
\hline $\begin{array}{l}\text { SciTech Life } \\
\text { Weekly }\end{array}$ & $\begin{array}{l}\text { www.bkweek.c } \\
\text { om }\end{array}$ & 2011 & Beijing & $\begin{array}{l}\text { Beijing } \\
\text { Youth Daily }\end{array}$ \\
\hline Donews & donews.com & 2000 & Beijing & $\begin{array}{l}\text { Beijing } \\
\text { Infinitas } \\
\text { Interactive } \\
\text { Media Co. } \\
\text { Ltd }\end{array}$ \\
\hline DivetheWorld & $\begin{array}{l}\text { WeChat public } \\
\text { account }\end{array}$ & 2013 & Beijing & $\begin{array}{l}\text { Dive the } \\
\text { World } \\
\text { (Beijing) } \\
\text { Cultural } \\
\text { Communica } \\
\text { tion Co., Ltd }\end{array}$ \\
\hline NewsLab & $\begin{array}{l}\text { WeChat public } \\
\text { account }\end{array}$ & 2012 & Guangzhou & Individual \\
\hline Global Watch & $\begin{array}{l}\text { WeChat public } \\
\text { account }\end{array}$ & 2015 & Guangzhou & Individual \\
\hline
\end{tabular}

Table 1: Basic information of eight journalistic start-ups in China. 
These eight news outlets were all founded in Beijing, Shanghai or Guangzhou after the year 2000. Toutiao and Donews are commercial online media outlets and represent the 'pure players', i.e. the media companies operating online only (Cook and Sirkkunen 2013). In contrast, the Paper, Airtime Weekly and SciTech Life Weekly are affiliated to newspapers and so outline the digital strategies of state-owned legacy media in China. The three WeChat public accounts run by former journalists represent independent journalism via social media (the Wemedia).

The author conducted a total of nine semi-structured interviews with informants from the eight outlets. Eight interviews were conducted via WeChat voice messaging in August 2016 and April 2018 respectively. The author conducted one face-to-face interview in Beijing in 2016, an interview that lasted about one hour. All interviewees were anonymized and pseudo names were given. Interviews were then transcribed by the author, table 2 gives a list of interviewees.

As some outlets were inaccessible, secondary literatures including online news reports, articles, and academic papers in both Chinese and English were analyzed in order to complement the interview results.

\begin{tabular}{|l|l|l|l|l|}
\hline Interviewee' s & Gender & $\begin{array}{l}\text { Position in } \\
\text { the media } \\
\text { pseudlo name }\end{array}$ & Media outlet & $\begin{array}{l}\text { Nature of } \\
\text { media outlet }\end{array}$ \\
\hline Aron & Male & Editor & Toutiao & Platform \\
\hline Bruce & Male & Management & Donews & Platform \\
\hline Chris & Male & Management & Donews & Platform \\
\hline David & Male & Management & Airtime Weekly & $\begin{array}{l}\text { Print } \\
\text { publication }\end{array}$ \\
\hline Frank & Male & Journalist & Airtime Weekly & Print \\
& & & publication \\
\hline George & Male & Management & SciTech Life Weekly & Print \\
publication
\end{tabular}




\begin{tabular}{|l|l|l|l|l|}
\hline Jason & Male & Management & NewsLab & Social media \\
\hline Sally & Female & Management & DivetheWorld & Social media \\
\hline
\end{tabular}

Table 2: List of interviewees

\section{Typology of Business Models for Journalism Start-ups in China}

On the basis of the newly proposed business model and secondary literatures, this article categorizes five business models for journalism start-ups in China (Figure 2).

Platform- $[$ News Aggregator (Today Toutiao)

Services Provider (Donews)

Content-
Oriented $\left[\begin{array}{l}\text { News Site Only (The Paper) } \\ \text { Trade Journal (Airtime Weekly, SciTech Life Weekly) } \\ \text { We Media (WeChat Subscription Accounts) }\end{array}\right]$

Figure 2: Typology of business models for journalism start-ups in China

Platform-oriented News Aggregator - A Case of Toutiao

Toutiao (Headlines) is a mobile news aggregation app in China founded in 2012 by Zhang Yiming, a former Microsoft employee. As "the tenth most-used app in China" (Feng 2017) and 'the number one news offering in China's iOS App Stor"', Toutiao has outpaced China's traditional news portals (Wang 2017). It aims to "become the world's number-one online content destination, eclipsing the likes of Facebook and Twitter, as well as the likes of the New York Times and Buzzfeed in their own markets.” (Knight 2017) 
By the end of 2016, Toutiao had 80 million daily active users who spent an average of 76 minutes reading news and watching videos, and more than $70 \%$ of its users are aged below 30 (Wang 2017).

Toutiao hosts but does not produce original content, its niche lies in its artificial intelligence (AI) and news sorting algorism. The app has developed some of the most sophisticated content-recommendation technology in the industry, basing recommendations on users' social media interactions and the content they consume. The company is also using artificial intelligence to weed out fake news and inappropriate content (Macfarlane and Wang 2017), as Aron stated to me: "We categorize articles and people along with machines. Toutiao depends on AI. It is the machine that makes recommendations. We play a complementary role and assist the machine to edit the content better" (personal communication, 2018).

Toutiao as a platform doesn't have its own staff writers. Only a few staff review the content to make sure this complies with state regulations. The content the app provides and recommends is sourced from more than 4,000 media companies that formed partnerships with Toutiao including both state-owned and independent media organisations such as Xinhua and Caixin (Macfarlane and Wang 2017; Feng 2017). To attract young users, Toutiao also provides bite-sized, Buzzfeed-style stories, cartoons, GIFs, live streaming shows and interactive Q\&A channels (Wang 2017). In addition, Toutiao has pushed into hosting user-created content; in 2016 , it invested $\$ 1$ bn in video streaming and now allows anyone to set up a channel on the app to post non-news content (Feng 2017).

Nearly all of Toutiao's revenue comes from advertising (Feng 2017). Since users spend an average of 76 minutes per day on the app, Toutiao has become an attractive destination for advertisers (Macfarlane and Wang 2017). Concerns over the sole source of advertising and the lack of original content have prompted Toutiao to seek additional sources of revenue abroad and to explore other service areas (Feng 2017). In February 2017, Toutiao acquired Los Angelesbased video app Flipagram, an Instagram rival, and has taken controlling stakes in several Indonesian and Indian media apps. It also formed partnership with Chinese ecommerce platform JD.com to enable users to browse and directly purchase JD.com products featured within the Toutiao app (ibid).

As a privately owned company, Toutiao is funded by a combination of investments and fundraising. In 2014, Sina Weibo, one of China's largest social media platforms, invested $\$ 100 \mathrm{~m}$ in Toutiao and now publishes non-news content by verified bloggers directly to Toutiao's app (Feng 2017). The company also received investment from Sequoia Capital in 2014 and Russian millionaire Yuri Milner in 2012. In its latest fundraising round in 2017, the company is seeking a valuation of $\$ 11$ billion (Knight 2017), though the overall value of Toutiao is believed to be overestimated. Investors demonstrate concerns over the ability of a company that provides content alone to sustain long-term growth, while Toutiao could also encounter problems associated with algorithm bias and fake news (Feng 2017).

Toutiao adopts a profit-sharing model with its content producers. As Zhang Yiming said at the Toutiao Accounts Creators Forum in Beijing in 2015 "the era of content producers has begun. We are now in the eve of the explosion of quality content" (Master Uncle 2015). In 2015, there were 35,000 accounts on Toutiao, of which 26,000 were We-media accounts, accounting for $73 \%$ of the total readings (ibid). Toutiao offers more than 1 billion yuan to encourage Wemedia's content production (Xia 2017). It does not require the content to be exclusive. Regarding the implementation of the profit-sharing model, Aron said: 
Toutiao and the authors share the advertising revenue. We don't have a fixed standard. The rate varies depending on different articles and advertisers. We have monthly financial statement about ads revenue. You can apply for it as long as you meet the conditions. You can also get income or bonus (hong bao) from Q \&A. But not everyone earns money from Q\&A. It is all based on machine algorithm. (Personal communication, 2018)

However it is still difficult for We-media to make considerable benefits from the profitsharing model. We-media users have expressed concerns that they are 'kidnapped' by online platforms and become concentrated via the profit sharing model (Xia 2017). Jason who runs an individual WeChat account commented:

In fact, no matter whether it is WeChat, Toutiao, NetEase or Phoenix, their profit-sharing model is not applicable to the accounts like mine. I tried but it did not work. I published one article every week with thousands of clicks. The advertising fee I obtained was only a few cents. It is ridiculous. The accounts that can obtain stable advertising revenue through the profit-sharing model are those that publish a large number of articles per day. They specialize in writing sensational headlines, fast production, and fast consumption. They obtain big ads revenue from online traffic. It is truly difficult to use this model on the social media platforms if you don't want to produce large-scale, low quality content that attracts traffic only. (Personal communication, 2018)

\section{Platform-oriented Service Provider - A Case of Donews}

Donews is a grown journalism start-up. Beginning as a blogging site for journalists and programmers in 2000, Donews is currently a B2B (Business to Business) new media company providing data and business intelligence services.

The users of Donews are businesses and organisations, media companies in particular, as Bruce states 'We are a B2B company. We provide services for Internet firms'. In 2012, Donews was registered as a company and donews.com became one business unit of the Beijing Infinitas Interactive Media Co. Ltd (the Company). The Company was later listed on NEEQ (National Equities Exchange and Quotations) in March 2016. Figure 3 shows the Company's structure.

\section{(Insert Figure 3 here)}

As an internet-based media company, the niche of Donews lies in the provision of panentertainment services as well as media data and business intelligence services. "Our company is unique because there are very few Internet companies that are profitable in China. We provide pan-entertainment services. We own technology media and gaming media. We are industry leaders in these two areas," said Chris (Personal communication, 2018). In 2015, the company integrated media resources and entered the big data and advertising market. As Bruce again elaborates "We have constructed the media data infrastructure integrating traffic, data, algorithm and intelligence. So we are a business intelligence service provider" (Personal communication, 2016). Having a R\&D centre staffed with more than 100 people, DoNews plans to enhance its computing capability and enter the neural network area. Meanwhile the company has involved itself in live casting businesses and has collaborated with other social media companies in China such as Douyu (China's largest live streaming site), BlueD and Flipboard China. 
DoNews' revenue streams consist of big data services and marketing. While the big data services account for $60 \%$ of the revenue, marketing revenue including advertising, PR and events accounts for the remaining $40 \%$. "We are not a pure advertising company. We want to become an Internet service company. In addition to advertising, we cooperate with video websites, live streaming sites, social media sites and so on," said Bruce.

The news content on Donews.com focuses on technology and games. In late 2017, Donews acquired a few game media/sites as well as launching an app (g.com.cn), similar to Toutiao, to distribute comprehensive news and information. While Donews.com does not generate much revenue, the company instead seeks to build a media brand, making and distributing IT news for branding purposes.

Donews is a public media company; funding sources include fundraising from equity market and institutional investors (Personal communication with Chris, 2018).

\section{Content-oriented News Site - A Case of The Paper}

The Paper is the first Chinese mobile news application featuring its own content (Speelman 2016). Launched in 2014, The Paper aims to become an open platform featuring current affairs, claiming to be a hybrid of Internet-based technological innovation and news values (thepaper.cn). The Paper started as an offshoot of the Oriental Morning Post, a stateowned print newspaper in Shanghai. On 1 January 2017, Oriental Morning Post ceased publication and all its news reports and opinions were transferred to The Paper. The Paper therefore represents the successful transformation from print newspaper to the digital app (Jiulianhuan 2017).

The target users of The Paper are the generation of Chinese citizens who use smartphones and social media (The Economist, 2014). Most of its readers are young and educated social elites, including middle level managers and above (Speelman 2016). These core users account for more than 30\% of its users (Yin, 2017) and by July 2017, the number of daily active users of The Paper reached 6.8 million (Jiulianhuan 2017).

The Paper's niche lies in the production of original content and in-depth political news, with anti-corruption news highlighted in particular. Having an editorial team of about 400 staff, The Paper's $80 \%$ of daily articles are original and exclusive (Yin 2017). The news app offers over 100 news and background stories a day in 49 categories ranging from rule of law to real estate to art (Speelman 2016). Its anti-corruption coverage is impressive, and corresponds with the on-going anti-corruption campaign since Xi Jinping came to power in 2012. Whereas the ruling Chinese Communist Party still gets its message out "in the style of America's Huffington Post" (The Economist 2014), The Paper, with its funding and aim of becoming China's premier political news platform, represents a potential revival of this ailing media climate in China (Speelman 2016). Together with the endorsement of Shanghai Communist Party Chief Han Zheng and the then Internet czar Lu Wei, such aims suggest that the outlet may start to adopt a more politically conservative approach to reporting in the future.

The Paper's revenue streams are comprised of copyright sales, advertising and brand activities, of which advertising income has the highest proportion. Such a profit model is ostensibly no different to that of traditional media, and, quite notably, The Paper is not a big money-maker and it is still exploring a feasible profit model. As Content Director Sun Xiang illustrates: 'The Paper needs to innovate its profit model' (Sun 2016). For copyright sales, CEO Liu Yonggang outlines the adoption of flexible approaches ranging from single text/picture, 
single video content, single column or channel, or the whole content: "We are optimistic towards the copyright sales in the future. In the next three years, the price of copyright may increase year by year.' Liu further elaborates: 'Reasons are double folded. First, people have re-recognized the value of quality content. Second, Internet news information will be further regulated. The content produced by We-media is limited' (Jiulianhuan 2017). With state backing, The Paper's mission is to 'gain influence without making anyone up top look too bad' (Speelman 2016) and, indeed, the Party 'may not care much about profit in this early stage of experimentation with new media formats' (The Economist 2014).

While this news app is currently free to online users there is a possibility that The Paper will adopt a paywall for specialized and subscribed content in the future, using tip jars or launching some subscription products: "We have a good name among the intellectuals and middle class. We also have resources. They may choose paid content for efficiency and personal interests," said Liu Yonggang. (Jiulianhuan 2017)

The Paper is funded by a mixture of state and private capital, obtaining initial (start-up) funding of 300 million to 400 million Yuan from the government and financing groups (Yan 2017). On top of the registered capital of 21.3 million yuan, the Shanghai Media Group, the Post's state-owned parent, contributed 100 million yuan $(\$ 16 \mathrm{~m})$ (The Economist 2014). In addition, Greenland Group contributed 100 million yuan, HONY Capital contributed 20 million yuan, and the management team contributed 40 million yuan (Zhu and Zhang 2014). 'The diversified stake holding is the biggest breakthrough of the new media projects of Shanghai Press Group.' (Yan 2017)

Due to such official support, The Paper enjoys many benefits that other media outlets may not have. The government's investment and backing, the geographical location of Shanghai as well as the human resources and branding of Shanghai Morning Post all contribute to the success of The Paper. Of all these factors, state ownership is perhaps the most important. 'The media is entering the licensing era. News gathering and editing, live streaming, short video all need licenses. The state background makes The Paper unique and unreachable.' (Jiulianhuan 2017)

\section{Content-oriented Trade Journal-Airtime and SciTech}

In 2011, Beijing Youth Daily (BYD), a media conglomerate under the administration of Beijing Youth League that owns ten newspapers, five magazines and two websites, launched two weekly magazines Beijing Weekend Airtime (Airtime) and SciTech Life Weekly (SciTech) in print editions. While the former is a lifestyle weekly, the latter is a science weekly covering the latest science and technological innovations.

The target readers of Airtime are businessmen and high-end travelers in their 30s to 50s. The circulation is 150,000 print copies. Bookstores at airports and five-star hotels in big cities such as Beijing and Shanghai are the main distribution destinations. Airtime also runs official Weibo and WeChat accounts. Readers can scan the code printed on the magazine and sign up the Weibo and WeChat accounts. Airtime's Weibo account has about one million followers. The new media business is supplementary to print editions. "Social media plays a marketing and branding role. They are meant to expand our influence," said David (Personal communication, 2016).

SciTech's target readers are science and technology professionals, science workers as well as general public who are interested in SciTech. "The offline readers are fragmented today. 
As a magazine, our production cost and consumption costs are high. We don't pursue the mass public. We pursue those who have certain influence," said George (Personal communication, 2016). The print publication is mainly based on group subscriptions with a circulation of more than 10,000 copies. SciTech has more than 200,000 users on its Weibo accounts and 70,000 users on its WeChat accounts. In 2016, SciTech launched its news app named SciTech Plus with 2,000 users.

The niche contents of Airtime and SciTech are different. While Airtime features its newswriting style for lifestyle stories, SciTech specializes in science communication. Both reach online users via news app and social media. "Airtime is not a publication with ads only. We want to make it newsy. We do in-depth coverage and every issue carries stories about hotspots from China and the world...We try to write lifestyle stories in the way we write news stories," said David (Personal communication, 2016)

However, Frank commented that this writing style is nothing new, being similar to advertorial language. According to Frank, new media has also posed challenges to in-flight magazines:

New media such as ipad and Wi-Fi will strike us heavily. The trend is that more and more flights start to provide free Wi-Fi onboard. People's reading patterns have changed from monologue reading to interactive reading on the Internet. Hainan Airline has its own ipad. Even though Wi-Fi is still unavailable on board, passengers can browse information or watch films on the airliner's ipad. The in-flight magazines will die out gradually.' (Personal communication, 2018)

SciTech is a trade journal in popular science and technology. It has a database of thousands of scientists, academicians and experts and its online and offline contents are different. SciTech's online services include a news app named SciTech Plus, a Weibo account named SciTech Agency, and a Wechat account named Kepu365. George explains the journal's new multiplatform production process:

Our production model is that we produce content online first, that is to say, right after the content is produced, we put it online and see the response of readers. If the online response is good, we select the content and include it in the print publication. Following the online publication, we will identify some issues. For example, some (online) users raise doubts and questions towards some coverage. We will follow their doubts and find answers by interviewing experts. Or we pursue and explore the leads, and then do follow-up reports online. Or we construct a complete report offline. Meanwhile some contents are printed first and then placed online. (Personal communication, 2016)

Revenue streams for Airtime and SciTech are also different. Advertising and offline ads in particular account for $90 \%$ of Airtime's revenue. The remaining $10 \%$ comes from hosting events/activities and direct sales. SciTech's revenue includes state subsidy, contracted services for government and businesses, subscription fees, and copyright sales. Revenue generated from contracted services for government agencies is SciTech's major financing source. Revenue from the content accounts for one fifth of the total revenue.

For both Airtime and SciTech, the online income from social media is minimal and, indeed, similar organisations tend to use this platform just for branding purposes: "We don't 
count on online services to make money. We put some offline coverage online to make it more interactive," said David from Airtime. "We actually make investment on the social media," said George from SciTech, "for some influential media outlets or We-media accounts, social media may generate some income. But the amount is usually small, which cannot support the operation of big media outlet."

Regarding the revenue model, George commented that content and distribution are separate. While the Internet-based revenue model focuses on investment, in reality investment may bring more users but creates little income in the short term:

Today the content and distribution channels are separate. The content I have produced is running on others' platforms. It is the platform that has real influence and makes big money. The platform will not generate much profits for the content producers. We just run our contents on the platform. (Personal communication, 2016)

As for the funding model, Airtime is solely funded by $B Y D$, the parent company. SciTech is funded by both $B Y D$ and Beijing Association for Science and Technology, while both titles are partially funded by the state.

\section{Content-oriented We-media-three cases}

As a veteran print journalist covering international news, Henry launched the GlobalWatch Wechat account in 2015 with seven other journalists. Aiming to cover the trends and events in global politics and economy, the group targets readers who are interested in global situations and international issues: "We started with a WeChat talking group first and then the public account followed. Within a short time, people from think tanks in and outside China, specialists in global issues, scholars and journalists joined the group. We are a loose alliance," said Henry (Personal communication, 2018). By the time of writing, there are more than 400 members in the WeChat group.

The niche content of GlobalWatch lies in its original articles and stances on international issues. For instance, the group organized a vote on ranking the top 10 most risky places in the world. They also hosted a seminar about the South China Sea on WeChat, which attracted about 400,000 reads: "We are different from those that incite nationalism. We have our own stances on some international issues. We believe we are objective and our stances are rational," said Henry.

Regarding the revenue streams, GlobalWatch is not commercialized and generates very little revenue from Tencent's ads: "We do this public account in our spare time. We also host some public seminars. GlobalWatch has a column called Perception Salon. We run about 10 issues addressing international issues... They are all non-profit....Currently, all the We-media that generate revenues are run by a team. They have full-time employees and they run it as businesses,' said Henry.

GlobalWatch is a non-profit individual WeChat public account without any external funding. Henry argues that the prime time for WeChat public accounts to make profits is now over, stressing that it is difficult to make profits from content in China if you don't have your distinctive feature and/or your own business model. Looking forward, he said: 
GlobalWatch can run well with re-positioning and re-formation of a team. There are challenges ahead. It is not easy to produce content, international news in particular. There is abundant international news information. It will be very difficult to have our own unique features. Next I may write articles in my personalized style. I may develop and give a personal touch to my public account. (Personal communication, 2018)

Jason started his WeChat account NewsLab in 2012 when he worked as a newspaper journalist in Guangzhou. NewsLab aims to introduce the latest innovations, practices and new business models in journalism and communication from the West to China.

NewsLab's target readers were media practitioners, academics and students at journalism schools. In September 2016, NewsLab launched its paid membership programme. Since then, NewsLab's free content targets the general public with a focus on media literacy, providing free information to help readers distinguish true or fake information.

In contrast to GlobalWatch, the niche of NewLab lies in its personal characteristics: "It started with my personal blog. Later I run the paid programme, hoping to increase the number of readers and impact," said Jason. "The uniqueness is being personal - my articles, my analysis, my angles, and my views. I write better than others on certain issues."

NewsLab's revenue streams include membership fee and advertising. It has approximately 1,000 members at present and the annual membership fee is RMB 300 yuan. The membership fee is the main revenue stream while advertising income accounts for a small percentage. Jason gave his reasons for his making profits from the paid content:

Since 2016, there has been a wave of paid content in China. My account has charged membership fees for about two years. It is mainly because people have realized that it is worth paying to buy the carefully selected and high quality professional content. Those free contents are all mass produced with inferior quality and sensational headlines.

Content has values. It is sellable. People recognize and accept it, and they are willing to pay to purchase it. It is actually a rectification to the online advertising model that is based on attention economy. Advertising model is traffic oriented. Production generates huge traffic but the quality of content is very low. There is so much junk traffic... Now it returns to the value of content. It is a good thing for content producers. (Personal communication, 2018)

As an individual account without any external funding, Jason said that it will be complex for NewsLab to obtain external investment: "I will need to register a company and I'll have to listen to investors. In that way, I'll have to run it as an entrepreneur project. It is not an entrepreneur project. It is just something I do in my spare time".

Sally was a journalist in Beijing. She started to learn diving in 2011. In December 2013, she started to run a WeChat pubic account named divetheworld. In June 2014, she established her own company Dive the World (Beijing) Cultural Communication Co., Ltd, offering mainly organised diving trips and sales of diving gear.

The target readers of divetheworld are professional divers and those who want to become divers. According to Sally, there are currently 300,000 to 400,000 active divers in China. The account has about 80,000 subscribers, which is the largest account in China's diving sector. The 
majority of users are from economically developed regions including Beijing, Shanghai, Guangzhou and Shenzhen, all whom account for $60 \%$ to $70 \%$ of subscribers. People in these areas are more affluent and have more disposable income, so can enjoy more complex and costly sports such as diving. Such subscribers could therefore translate into real customers.

The niche content of divetheworld is diving related information. News information accounts for a small portion of the content. "Lately I started to release more information about diving tourism and islands tourism. Those articles have a high reading rate," said Sally. Most articles are edited or reprinted from other domestic or foreign news sources. "Our strength is that we release articles frequently, five articles per day. We try to make our content readable, practical and fun, and not too commercial." (Personal communication, 2016).

The revenues of Dive the World (Beijing) mainly come from tourism, accounting for 80 to $90 \%$. Advertising and sales of diving gears account for 10 to $20 \%$ of revenue. Content does not generate revenue: "We are not VIP accounts that charge a lot for every piece of ads. We don't have a large number of fans, thus we can't charge much from advertisers," said Sally. "We tend to use content to accumulate users. The online readers will turn into our customers. We generate revenues from customers through our offline products. This is our model. We don't make money from content."

Weibo and WeChat's official accounts launched the "tip" function in 2014 and 2015 respectively (Liu 2016). Online users could tip the author voluntarily after reading the article. As the tip function becomes common, some articles can get thousands of tips and more than one hundred thousand clicks. "It has been fostering the growth of independent journalism on social media....Weibo and wechat's official accounts have also become platforms where people could create and consume news content" (ibid). However, for divetheworld, the tip function as a reward system brings in little cash, less than 50 yuan per month. Sally said:

Our original articles have the tip function. But the money we make from it is very little. The tip function is more suitable for individual accounts that have unique personal touch. You are one person talking to everyone. Others feel like they are talking to you while reading your article. They tend to tip you. But we are a company writing articles and doing things. People would think you are an organization and you don't need me to tip you. If you are an individual, people are willing to support you. (Personal communication, 2016)

The success of the tip function therefore depends upon the nature of the social media account, possibly working more for individual accounts than corporate accounts.

\section{Discussion and Conclusion}

Having applied the newly proposed business model for digital journalism in eight cases in China, the five types of journalistic start-ups' business models are summarized and discussed further below:

First, mobile based news aggregation apps are big business in China. In 2017, Toutiao and Tencent news are leaders in this market with a penetration rate of $20.7 \%$ and $19.8 \%$ respectively (askci.com, 2017). The big news aggregators such as Toutiao target the general public through delivery platforms of mobile apps and websites. They specialize in artificial intelligence and news sorting algorisms. Advertising is their sole revenue stream. As commercial 
platforms, the news aggregators' funding sources include private investors and financing groups. Unlike other types of journalism start-ups, news aggregators have started to implement profitsharing model with content producers to overcome the legal issues and to attract more quality content. However such profit-sharing model does not work for the We-media represented by many individual WeChat accounts, indeed the power imbalance between the platforms and content producers is significant. The platforms have concentrate power through determining the exposure of articles based on algorisms and clicks (advertising).

Second, for the platform-based service providers, news provision is not their core business. Instead, online news is run mainly for corporate branding purposes. These Internet firms target businesses and make profits from diversified non-news services, of which Donews is a good example. While Donews still maintains a news unit that produces, edits and aggregates IT news and information on their website (donews.com), this unit does not generate much revenue. Instead, as a public media company funded by an equity market and institutional investors, Donews generates revenue from providing big data and marketing services.

Third, The Paper is the best case to represent the legacy media's adoption and implementation of digital strategies facilitated by the Chinese government. In 2014, President Xi Jinping stated that 'the convergence of traditional media and new media development has become a major national strategy in China' (Sparks et al 2016). The 'Two W (Weibo and WeChat) and one app' (两微一端) has also become an industry standard for Chinese media (askci.com 2017). Both national level media such as Xinhua, CCTV and People's Daily as well as provincial level media such as Shanghai Media Group have responded quickly through more investment and innovations in their convergence activities (Sparks et al 2016).

The Paper, launched as part of the Shanghai Media Group, targets social elites and specializes in original content and in-depth political news. Its revenue model is similar to that of traditional media featuring advertising, copyright sales and brand activities. The funding model is different from the commercial platforms or websites. The Paper draws state funding via Shanghai Media Group and private capital via financing groups. This state ownership allows the company to enjoy a unique position in the market competition.

Fourth, while print newspapers are struggling and many have closed down in the West and in China, some Chinese newspaper conglomerates launched new trade journals in the fragmented media market. For instance, Airtime targets business people and publishes lifestyle content in a fairly conventional newswriting style. SciTech's users are professionals, young people, civil servants, and parents. Its content specializes in scientific and technological innovations. Both publications are partially state-funded and both have used apps and social media for marketing purposes. Their revenue models are mostly traditional with revenue coming from advertising, direct sales, subscription, copyright sales and through hosting offline events and activities. In addition, SciTech has developed an app (SciTech Plus) for science communication and makes profit from contracted services for government administrations and businesses.

Fifth, WeChat is an integrated eco-system (Chen 2016). The development and spread of We-media in China peaked when WeChat's public account service was launched in 2012, helping to foster many new business models (tmtpost 2015). The WeChat account has become a starting point for many entrepreneurs since it is easily accessible and cost-efficient (ibid). The three cases demonstrate that this niche content/market is extremely important for individual accounts. GlobalWatch focuses on international news and analysis, NewsLab provides professional media content for its registered members and free media literacy content for general 
public, while Divetheworld provides specific information to divers. Their revenue streams include membership fee, advertising and offline businesses. They receive no external funding. Since late 2014, the influence of individually-run WeChat public accounts has begun to diminish due to WeChat's registration system when WeChat shifted its focus to company-run public accounts (tmtpost 2015). In order to make profits and maintain influence, the individual WeChat public accounts need to register as company as a means to get into groups for mass production and sales, and to personalize the accounts' content.

To summarize, journalism start-ups can be broadly grouped into platform and content oriented categories. Each category holds different types of business models. Platform-oriented news aggregators and service providers (Type 1 and 2) are technology-driven commercial outlets with revenue streams of advertising, marketing, big data and other services. Content-oriented news sites and trade journals (Type 3 and 4) are state-owned and partially state-funded. Their revenue model is similar to that of traditional media featuring advertising, copyright sales, subscription or direct sales. For We-media represented by WeChat public accounts (Type 5), there are diverse forms of content and multiple revenue streams depending on the size and nature (individual or company) of the accounts. Social media does not generally generate much revenue to content producers except for a few influential media outlets and social media accounts. Instead Social media is mainly used as a distribution channel for marketing and branding purposes.

These five types of business models for Chinese journalism start-ups are driven by state policy, economic markets and technology. The state media policy is fundamental in determining the business model for news outlets. While Chinese news media have become liberalized and commercialized in the post-WTO era, they are still under political and regulatory constraints. Commercial news sites (portals) are not permitted to report original news stories (Zhang, 2012) and websites require Internet Content Provider (ICP) licences to operate legally, with licences generally only granted to large organizations. Since early 2001, state-owned non-media investors are allowed to become shareholders of the Chinese media under the condition that the state still controls the majority of the news media company's shares (Zhang, 2010), hence "there has not been the same proliferation of new, smaller-scale, news providers in China as we see in the West". Instead the emerging news websites are "the product of joint ventures between existing news organizations and large online commercial operations" (Sparks et al 2016). These policies also explain why platform oriented commercial news sites are either news aggregators or service providers with a focus on non-news businesses, and the content-oriented news sites and trade journals are all state owned and partially state-funded with strong state backing. The Paper, Airtime and SciTech's experimentation with new business models all reflect the implementation of the state's national strategy in the media's transition from print to digital forms.

Market and digital technology innovations also contribute to the development of business models. The press market in China has expanded substantially due a general trend in both urbanization and the rise in living standards (Sparks et al 2016). In fact, newspaper advertising rose from 2011 while circulation rose by about $20 \%$ between 2004 and 2013 (ibid). Meanwhile Chinese media market remains fragmented and differentiated, which enables the entry and growth of different types of journalistic outlets, e.g. the niche publications Airtime and SciTech. With the diffusion of Internet, mobile phones and social media in China, nearly all news outlets have multiple delivery platforms ranging from websites, Weibo and WeChat accounts, to apps. 
Technology-savvy and financially robust platforms have also developed artificial intelligence and big data services.

The policy, market and technology has also enabled and facilitated the development of We-media. Individuals and businesses alike use WeChat as a platform to either publish their content, generate revenues or for marketing and branding purposes.

In conclusion, Chinese journalism start-ups have explored innovative business models that are appropriate to China's specific political and social context. The proposed new business model is a feasible means to analyse and explain the status of journalism start-ups in this national context. New revenue streams can be identified, including but not limited to big data services, contracted services for government organs, state subsidy, and the tip function on WeChat. Others, such as the mixed funding model of state and private capital, the profit sharing model, and WeChat-based entrepreneurs, are all innovative with strong Chinese characteristics.

Finally, the limitations of this study lie in the number of case studies. Future research may examine larger data sets of Chinese journalism start-ups as well as cross-cultural analysis of business models for digital journalism, thus revealing more diverse and differentiated business models.

\section{REFERENCES}

Askci.com. 2017. 2017 news app report: Today Toutiao and Tencent. http://www.askci.com/news/chanye/20170331/09375394737.shtml. Retrieved 6 July 2017

Anderson, Chris. 2007. The long tail: how endless choice is creating unlimited demand, London: Random House Business

Brandstetter, Barbara, and Jessica Schmalhofer. 2014. Paid Content, Journalism Practice, 8:5, 499-507

Chyi, Hsiang Iris. 2012. Paying for what? How much? And why (not)? Predictors of paying intent for multiplatform newspapers, International Journal on Media Management, 14:3,227-250

Chyi, Hsiang Iris, and Angela M. Lee. 2013. Online news consumption, Digital Journalism, 1:2, 194211

Chyi, Hsiang Iris, and Ori Tenenboim. 2017. Reality Check, Journalism Practice, 11:7, 798-819

CNNIC. 2017. The 40th China Statistical Report on Internet Development (第40次中国互联网络发展 状况统计报告).

http://112.17.13.223/files/1195000004BE54AD/cnnic.net/hlwfzyj/hlwxzbg/hlwtjbg/201708/P02 0170807351923262153.pdf. Retrieved 2 August 2017

Cook, Clare and Esa Sirkkunen. 2013. What's in a Niche? Exploring the Business Model of Online Journalism, Journal of Media Business Studies, 10:4, 63-82

Feng, Emily. 2017. Toutiao touts AI for individual news in vast China market, Financial Times, 10 May. https://www.ft.com/content/04b55fdc-28b7-11e7-9ec8-168383da43b7. Retrieved 18 July 2017

Foss, Nicolai J. and Tina Saebi. 2017. Fifteen Years of Research on Business Model Innovation: How Far Have We Come, and Where Should We Go?, Journal of Management, Vol. 43 No. 1: 200227

Gahran, Amy. 2013. Business models for digital journalism startups around the world. http://www.knightdigitalmediacenter.org/news/2013/01/business-models-digital-journalismstartups-around-world.html. Retrieved 4 August 2017

Graybeal, Geoffrey and Jameson Hayes. 2011. A modified news micropayment model for newspapers on the social web. International Journal on Media Management, 13 (2), 129- 148.

He, Shulong. 2014. Zhang Yiming at Jinri Toutiao: How to play with the 3 billion value? 31 May, https://www.huxiu.com/article/34793/1.html. Retrieved 17 July 2017 
Jiulianhuan. 2017. What lessons can Pengpai bring us three years after its launch? 25 July. https://36kr.com/p/5084985.html. Retrieved 5 September 2017

Ju, Alice, Sun Ho Jeong and Hsiang Iris Chyi. 2014. Will Social Media Save Newspapers?, Journalism Practice, 8:1, 1-17

Knight, Will. 2017. The Insanely Popular Chinese News App That You've Never Heard Of, 26 January. https://www.technologyreview.com/s/603351/the-insanely-popular-chinese-news-app-thatyouve-never-heard-of/. Retrieved 18 July 2017

Lee, Angela M. 2015. Social Media and Speed-Driven Journalism: Expectations and Practices, International Journal on Media Management, 17:4, 217-239,

Leurdijk, Andra. 2014. Funding Models for Online News. In Michał Golwacki, and Lizzie Jackson, (eds.) Public Media Management for the Twenty First Century: Creativity, Innovation, and Interaction. London: Routledge, pp.143-160.

Liu, Louis. 2016. "A Comparative Study of Crowd Funding Journalism in China, Taiwan and the UK", Reuters Institute for the Study of Journalism. http://reutersinstitute.politics.ox.ac.uk/ourresearch/comparative-study-crowd-funding-journalism-china-taiwan-and-uk. Retrieved 18 November 2017

Macfarlane, Alec and Serenitie Wang. 2017. China's \$11B app that wants to organize the world's information, CNN, 12 June. http://money.cnn.com/2017/06/12/technology/china-toutiao-newsapp/index.html. Retrieved 18 July 2017

Machin, David and Sarah Niblock. 2010. The new breed of business journalism for niche global news, Journalism Studies, 11:6, 783-798,

Master Uncle. 2017. RMB 10,000 a month. How does Toutiao share profits with We-media? 29 September, http://www.jiemian.com/article/375687.html. Retrieved 3 October 2017

Pavlik, John V. 2013. Trends in New Media Research: A Critical Review of Recent Scholarship. Sociology Compass 7 (1): 1-12.

Pickard, Robert. 2011. Mapping Digital Media: Digitization and Media Business Models, Open Society Foundations Media Programme. https://www.opensocietyfoundations.org/sites/default/files/digitization-media-business-models20110721.pdf. Retrieved 3 November 2017

Pickard, Victor and Alex T Williams. 2014. Salvation Or Folly? Digital Journalism, 2:2, 195-213

Sirkkunen, Esa and Clare Cook. 2012. Chasing Sustainability on the Net: International research on 69 journalistic pure players and their business models.

http://tampub.uta.fi/bitstream/handle/10024/66378/chasing_sustainability_on_the_net_2012.pdf? sequence $=1$. Retrieved 22 September 2017

Sparks, Colin, et al. 2016. The impact of digital media on newspapers: Comparing responses in China and the United States, Global Media and China, Vol. 1(3) 186-207

Speelman, Tabitha. 2016. 'Looking for Smarter, Sexier Chinese State Media? There's an App for That', Foreignpolicy.com, 15 December. http://www.publicdiplomacycouncil.org/commentaries/01-0416/quotable-tabitha-speelman-chinese-news-app. Retrieved 17 July 2017

Statista.com. 2017. Number of monthly active WeChat users from 2nd quarter 2010 to 2nd quarter 2017 (in millions), https://www.statista.com/statistics/255778/number-of-active-wechat-messengeraccounts/. Retrieved 2 October 2017

Stetka, Vaclav and Henrik Örnebring. 2013. Investigative Journalism in Central and Eastern Europe: Autonomy, Business Models, and Democratic Roles, The International Journal of Press/Politics, 18(4) 413-435 
Teece, David. J. 2010. Business Models, Business Strategy and Innovation, Long Range Planning, Volume 43, Issues 2-3, Pages 172-194

The Economist. 2014. Propaganda 2.0, 11 December. https://www.economist.com/news/china/21636090-once-caught-back-foot-social-mediacommunist-party-has-upgraded-its-propaganda. Retrieved 24 July 2017

Tmtpost. 2015. The Evolution of We-media in China, tmtpost, 13 June, http://www.tmtpost.com/233235.html. Retrieved 15 November 2017

Tmtpost. 2017. Chinese Financial News Pioneer Caixin Media Starts Charging Readers for its Quality \& Professional News Service, tmtpost, 18 October 2017, http://www.tmtpost.com/2858325.html. Retrieved 18 November 2017

Wang, Yue. 2017. China's $\$ 11$ billion news aggregator Jinri Toutiao is no fake, Forbes, 26 May, https://www.forbes.com/sites/ywang/2017/05/26/jinri-toutiao-how-chinas-11-billion-newsaggregator-is-no-fake/\#148684f64d8a. Retrieved 17 July 2017

Wirtz, Bernd W. 2011. Media and Internet Management, Auflage: Gabler

Wirtz, Bernd W., Adriano Pistoia, Sebastian, Ullrich, and Vincent Göttel. 2016. Business Models: Origin, Development and Future Research Perspectives, Long Range Planning, Volume 49, Issue 1, February 2016: 36-54

Xia, Shouzhi. 2017. A Study on the Profit Model of We-media in China, Global Media Journal, Vol. 15 No. 28: 69. http://www.globalmediajournal.com/open-access/a-study-on-the-profit-model-of-wemedia-in-china.pdf. Retrieved 24 July 2017

Zhang, Shixin Ivy. 2010. Chinese Newspaper Ownership, Corporate Strategies, and Business Models in a Globalizing World, International Journal on Media Management, 12: 3, 205-230

Zhang, Shixin Ivy. 2012. 'Newsroom of the future: newsroom convergence models in China', Journalism Practice, Volume 6, Numbers 5-6, pp. 776-787(12). 